\title{
Institutionalizing the Empirical Evidences on Successful Case of Institute- Post Office Linked Technology Dissemination Model in India
}

\author{
S.K. Dubey ${ }^{1 *}$, R.R. Burman ${ }^{1}$, J.P. Sharma ${ }^{1}$, K. Vijayaragavan ${ }^{1}$, \\ Sujit Sarkar ${ }^{2}$ and H.S. Gupta ${ }^{1}$ \\ ${ }^{1}$ ICAR-Indian Agricultural Research Institute (IARI), New Delhi, India \\ ${ }^{2}$ ICAR-Agricultural Technology Application Research Institute (ATARI), Kanpur, India \\ *Corresponding author
}

Keywords

Technology dissemination, Post offices, Unreached farmers, Agricultural technologies

Article Info

\section{Accepted:}

26 October 2017

Available Online:

10 January 2017

\section{A B S T R A C T}

The sufferings and bottlenecks of main extension systems in India are well deliberated and documented. The search for evolving the alternate innovation system for agricultural technology dissemination is rigorously pursued at national level. Five yearly (2009-10 to 2014-15) research project on technology dissemination for the distantly located farmers were executed by linking the public funded institution of village post offices of India and the premier agricultural research institute ICAR-Indian Agricultural Research Institute (IARI), New Delhi. The experiences emanated from this research were empirically reported. From the modest beginning of linking with seven post offices in the only state of Uttar Pradesh, the model is being successfully in operation across 13 states of the country with involvement of 130 village based post offices across 36 districts of the country. With the institutional arrangement mutually agreed between the concerned department of post and department of agriculture, the figure is expected to be 500 post offices across 100 districts of the country in time to come on public-public partnership model. On all possible techno-economic and organizational parameters, the model proved not only to be timely, cost-effective and replicable rather sustainable also. The model has strong in-built mechanism to reach to the unreached farmers of the country and making agriculturally technologies accessible to them.

\section{Introduction}

The significance of agricultural extension in achieving the aim of agricultural and rural development through education and transfer of knowledge, skills and technology has been well established (Feder et al., 2011). Albeit, the extension systems and delivery methods in vogue especially in many developing countries have been constantly viewed as moving parallel and non-convergent to the demands and technological challenges apropos clients' diversity and ultimately in reaching the rural poor (Birner et al., 2004). Dissemination of agricultural and related technologies generated by public sector research organizations through appropriate delivery mechanism such as demonstrations, field visits, farmers' meetings, use of media etc have, by and large, remained the major role of agricultural extension in developing countries. This 
process had the theoretical backstopping from the 'diffusion of innovation' model as suggested by Rogers (1962). The farmer participation in technology development and client's participatory extension approaches have emerged as a response to such thinking. The notion of extension as part of a wider system has emerged, for example, the 'interdependence model' (Bennet, 1992) and the 'innovation systems framework' (Lundvall, 2007) offer more inclusive ways of thinking about the actors and the institutional context in which the generation, diffusion and use of new knowledge takes place. With the globalization of agriculture, major emphasis is laid on increasing productivity and profitability and, therefore, approach of production-led and market-led extension becomes indispensible (Duraisumy'2007).

Thus, revamping of extension system will certainty play a catalytic role for ushering in farmer-led and market-led extension (Moni' 2004) which can subsequently alleviate poverty and in this context, the importance of institutional reconstructing and renewal, and decentralized extension structure is important (Samanta' 1991). Recently, many developing countries have reaffirmed the essential role that agricultural extension can play in agricultural development as pointed out by Birner and Anderson (2007). Chambers et al., (1989) evolved the concept of Farmer First which was established as paradigmatically different from TOT, and vital for complex, diverse and risk prone agriculture. Ian Scoone and John Thompson (1994) came with Beyond Farmer First concept. This stressed perspectives that broadened and complemented Farmer First: the pluralism of different knowledge; the recognition of knowledge as not a stock but a process; seeing farmers, extensionists, scientists and others as social actors; recognizing political dimensions and the significance of power relations; and elements of a new professionalism in agricultural science. Thus, the trends in evolution of extension model, approaches and methodologies have witnessed a highly dynamic scenario both at global and National level. This gives the clue for continuous experimentation, adaptation, application, discontinuance and regenesis of new model if the farming community and other stakeholders to be served better.

\section{Rationale for Institute-Post office Linked technology dissemination}

Evidently enough, public-sector extension, the main source of technology and information delivery to Indian farmers at large, has been proved to be less accessible to the majority of the farmers who are remotely located across the country. At the same time, the shifting emphasis of the Indian agriculture towards diversification, income enhancement, efficiency and commercialization of farming $v i s-a$-vis the widening gap of extension worker-to-farmer ratio in the country, the search for alternative frontline extension approaches has become inevitable so as to ensure farmers' access to the agricultural technologies for enhancing their farm productivity and income. The central problem of wide current extension worker to farmer ratio in India (1:5000) as compared to China (1:625) (Ragasa' 2013) besides the fact that about $40 \%$ of the field level extension workers are not in position (Chandragowda' 2011) are the antecedents for initiating this research at the National level. This fact also implies that on an average, the existing strength of extension services only reach to $6.8 \%$ of farmers of the country (GFRAS' 2012). Further worsening the situation, at least $25 \%$ extension workers are in administrative or supervisory position who are not directly in touch with farmers. With remaining extension workers, at least $50 \%$ of their times goes for administrative work, official correspondence, works of health 
department, census works, panchayat departments work i.e., in non-farm activities. Thus, the efficacy of main extension system could be easily comprehended.

The Indian Postal Services were established in the current format largely under and for the East India Company. The system was reorganized and the service opened to the general public by Warren Hastings in 1774. In 1835 a committee was set up for unification of custom and postal system of all the presidencies. The result was the first Indian Post office act of 1837.

It not only provides for uniform rates and routes but for the uniform designs and other specifications of the postmarks for each category of post office. The Indian Postal Service, with 1,55,015 post offices (staff strength-474574) of which 1, 39,144 $(89.76 \%)$ are in the rural areas, is the most widely distributed post office system in the world (Department of Post, 2014).

On an average, each Post Office serves the contiguous area with manageable rural population. Owing to this far-flung reach and its presence in remote areas, the Indian postal service is also involved in other services such as small savings banking and financial services. Rural branch post office caters to limited number of villages/post office and the branch post masters (BPM) are mostly the farmers with rural background. It is also a matter of fact that the village based BPM are the agricultural farmers as their assigned job is semi-permanent in nature.

Thus, the working and locale of the rural post offices in the country gives clue for exploring the possibilities for making them as the potential partner in disseminating the agricultural related technologies and information. This also led to emergence of the possibility of evolving the public-public partnership based extension system in the country. From the experience of Republic of
Korea, postal services were found successfully utilized for e-commerce and farming particularly fish farming for marketing of the produce using ICT enabled technologies (ITU, 2010) which may be further explored for such possibilities in Indian context.

Against the above adequate cases supporting the validation of rural post-offices of the country to act as the technology delivery centers and knowledge and information centers for the distantly located farmers, following research questions were investigated empirically, namely what were the situations favouring the rural post offices to be the partner in agricultural technology dissemination system?, what were the circumstances of the farmers located in farflung areas for exploring the possibilities of evolving post office as the village based technology and information centers?, what are the roles of branch post masters as community based change agent?, what could be the efficiency of post offices in the process of technology delivery with what nature of postoffice - farmer - institute partnership?, what is the viability of such proposition to be evolved as the replicable model?, what are the strength, weakness, opportunity and potential threat in such model? and how the model could be institutionalized as the frontline extension model at National level?

\section{Materials and Methods}

As a part of institute research project of ICAR-Indian Agricultural Research Institute (IARI), New Delhi, namely - Cyber Extension Model for Agricultural Development: An Action Research (IARI:AEX:09:1), establishing linkages with post offices of selected villages and study its effectiveness in communication of farm information and technologies was also kept as the major activity. 


\section{Pilot stage}

At the pilot level, the project was implemented in the Sidhauli and Kasmanda blocks of Sitapur district of Uttar Pradesh during rabi 2009-10. Seven Gramin (rural) post offices from five clusters of villages namely, Gandhauli, Neelgaon, Amberpur, Behma, Manwa, Chaudia Manpara and Rehua were identified for the study. Action-Research was conducted phase-wise. In the first phase, exploratory and descriptive study on possibility of establishing linkages with post office in dissemination of IARI technology was done. The post office personnel $(n=50)$ at district, block and villages levels were contacted and interacted to explore the possibility. The analysis of organisational structure of Indian Postal department was also done. The post office personnel were interviewed on the parameters of possible linkage activities, perceived mechanism to establish such linkage and also trend analysis of postal work load since last ten years (since the mobile telephony gained momentum) was also done. Based on the experiences of first phase, the suitable crops and their varieties were identified and disseminated through postal network in second phase. The analysis of performance of these crops were done in terms of area coverage, yield obtained, total quality produce generated for further use, and their economics for high volume-high value and low volume-high value crops. Post offices personnel's and farmers' perception were ascertained and correlated to see the degree of convergence. The impact of capacity building programme for farmers and post office personnel was ascertained on selected behavioural dimensions.

\section{Validation stage}

At this stage, a total of 1921 farmers from 181 villages covered under 18 post offices of five states namely Uttar Pradesh, Madhya Pradesh, Bihar, Rajasthan and Jammu and Kashmir were involved for further validation of the model. At this stage, relative impact of various approaches tested for seed dissemination through post offices according to farmers and post office staff were ascertained, diffusion effect of quality seeds disseminated was quantified, economic validity of the model was ascertained for high - low value and low volume - high value crops on cost sharing basis, perception of the stakeholders like farmers, scientists and the post office personnel and effect of capacity building programme were analyzed.

\section{Upscaling stage}

After receiving the encouraging success at above stage, a working functional model was devised for upscaling this innovative approach across 56 districts of 13 states in India. Krishi Vigyan Kendras of these districts were made as the important partner at this stage with their definite role of technology backstopping to the post office personnel, multiplication of quality seed for further dissemination through retail post. Therefore, all the Agricultural Technology Application Research Institutes (ICAR-ATARI) representing eight zones were made as the active partners at this stage.

\section{Institutionalization stage}

In order to sustain the model on time and space, a Memorandum of Understanding (MoU) was agreed between the Ministry of Communication and Department of Post, Government of Indian and ICAR-Indian Agricultural Research Institute (IARI), New Delhi. The MoU envisaged 128 Branch post offices across 13 states shall be covered under IARI-Post Office Linkage Extension Model and as per the tie-up, the identified BPOs have to provide agricultural related services to the farmers under the closed partnership with ICAR-IARI, New Delhi and concerned KVKs of the identified district. The Indian Council 
of Agricultural Research, Ministry of Agriculture, Govt. of India has also accepted to institutionalize this model as KRISHI DAK. Besides, this innovative model has been mentioned in the Demand for Grants (201415) document of Committee on Agriculture (2014-15) by DARE, Ministry of Agriculture submitted in Sixteenth Lok Sabha.

\section{Results and Experiences}

\section{Efficacy of post offices in technology and information delivery through post-office - farmer - institute partnership}

Dissemination of quality seed: During the period of 5 years (2009-10 to 2014-15) total of 5299 farmers from five states already availed the IARI technological services through post office. Eight major IARI wheat varieties and nine popular rice varieties (both basmati and non-basmati) were disseminated in five states based on the farmers' demand. Beside rice and wheat, other poplar IARI varieties like Pusa Jaikisan, Pusa Bold of Mustard, Pusa 383, Pusa 443 of Pearl millet, Pusa Naveen of Bottle gourd, Pusa Viswas of Pumpkin, Pusa A4 of Bhindi, Pusa Narangi Gainda of marigold were disseminated. In this way, total 30 improved and high yield varieties of 13 crops for all the three cropping seasons were disseminated in this process.

Over the years, the project expanded both horizontally and vertically. Similarly, the confidence and expectation of farmers from this premier institute also steered up. Based on farmers' demand, other technological services like bio-fertilizer, pesticide etc beside improved IARI varieties. As a result, ICARIARI also disseminated BGA and Pusa hydrogel among the needy farmers. Besides seeds, the information packages were also sent to the farmers by post.
The response of post offices in disseminating the seed for three initial seasons have been shown as below:

It was observed that more than 90 per cent of farmers received the seed of above crops sent through post office within 4-6 days of dispatch as indicated in the above graph.

Enhancing farmers' level crop productivity: The improved varieties of crops disseminated through this mechanism revealed two specific observations. Firstly, the adaptability of the varieties was assessed in various microfarming situations of the project villages and secondly, the yield advantages from such appropriate varieties could be quantified over their prevailing crop varieties. Not only this, the relative economics of the crop varieties obtained from the district agricultural departments could also be assessed as compared to the potential of ICAR-IARI, crop varieties. As a result, the yield gap in the four major crops namely paddy, wheat, bajra and mustard could be minimized considerable (30-67\%) which is depicted as below.

\section{Differential economic viability of the model as compared to the seed availability from local market/district agricultural department}

The comparative economic viability of the model as compared to the seed made accessible to the farmers through local market/district agricultural department was also worked out on different economic indicators. The analysis, again favoured the model, thereby making it viable.

The experiences further consolidated that the experimented model had comparative advantages from the local market or the district agricultural department for making crop husbandry more remunerative by making the quality seed available to the farmers. 
Fig.1 Year wise performance of seed delivery through post offices

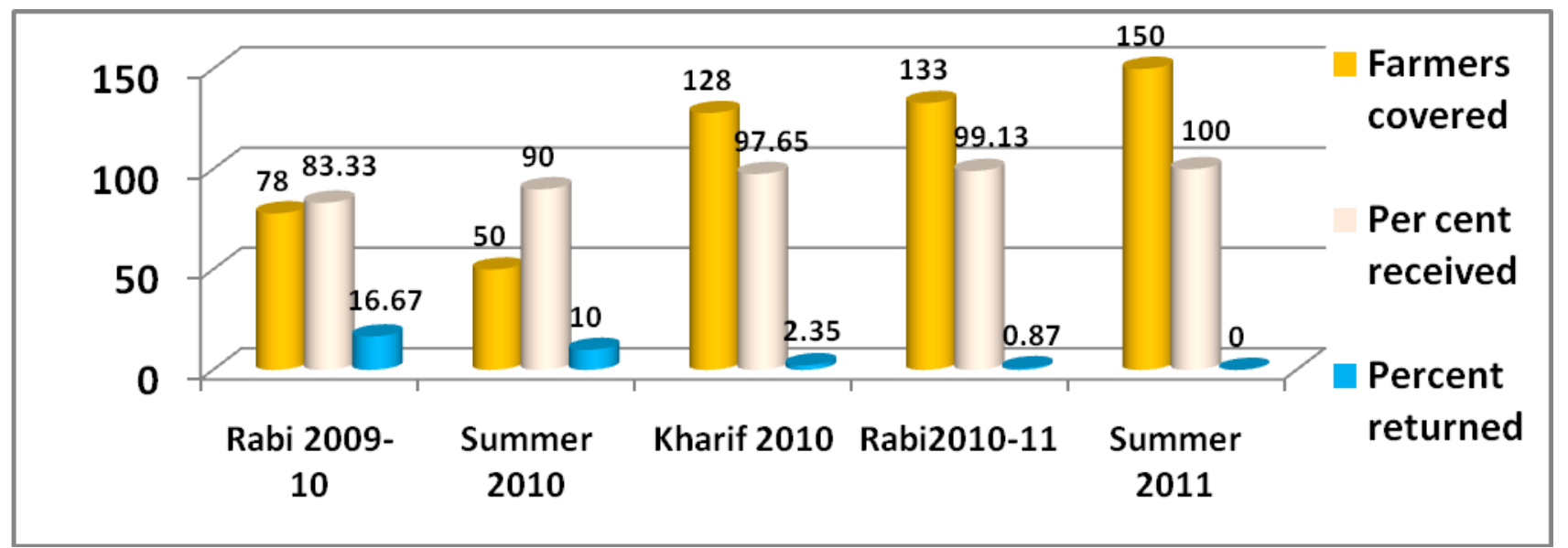

Fig.2 Extent of yield gap minimized due to IARI varieties disseminated though post office

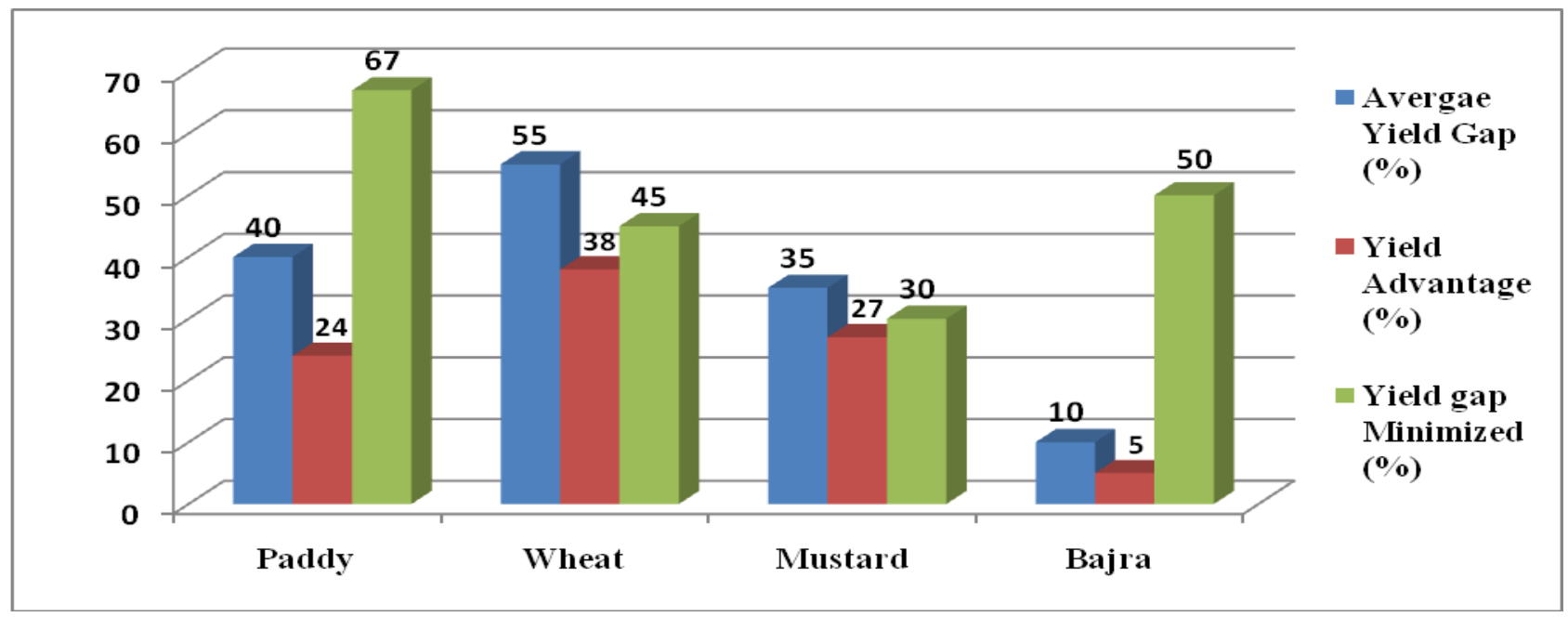

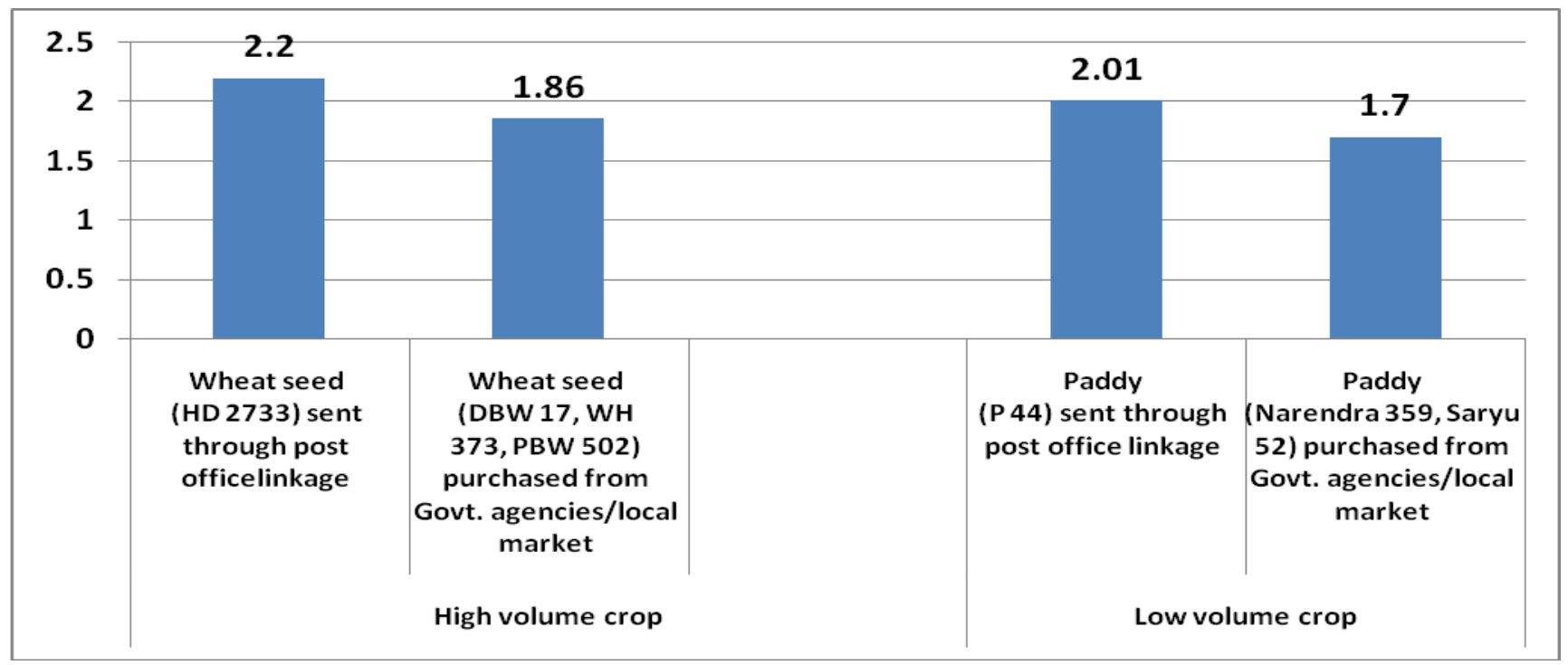


Table.1 Diffusion effect of quality seeds of paddy and wheat disseminated through post office

\begin{tabular}{|c|c|c|c|c|c|}
\hline \multirow[t]{2}{*}{ Crops } & \multirow[t]{2}{*}{ Year } & \multirow{2}{*}{$\begin{array}{c}\text { Seed } \\
\text { Supplied }\end{array}$} & \multicolumn{3}{|c|}{ Seed multiplication and diffusion over the years } \\
\hline & & & 2012-13 & 2013-14 & 2014-15 \\
\hline \multirow[t]{3}{*}{ Wheat } & $2012-13$ & $\begin{array}{l}14 \mathrm{q} \\
(14 \mathrm{ha})\end{array}$ & $\begin{array}{l}630 \mathrm{q} \\
\text { (@45 q/ha) }\end{array}$ & $\begin{array}{l}252 \text { q (252 ha, @ } 40 \% \text { as } \\
\text { seed) } 11340 \mathrm{q} \\
\text { (@ } 45 \mathrm{q} / \mathrm{ha} \text { ) }\end{array}$ & $\begin{array}{l}4536 \mathrm{q}(@ 40 \% \text { as seed }) \\
4536 \mathrm{ha}\end{array}$ \\
\hline & \multirow[t]{2}{*}{ 2013-14 } & \multirow[t]{2}{*}{$\begin{array}{l}72 \mathrm{q} \\
(72 \mathrm{ha})\end{array}$} & \multirow[t]{2}{*}{--} & $\begin{array}{l}3240 \mathrm{q} \\
\text { (@45 q/ha) }\end{array}$ & $\begin{array}{l}1296 \mathrm{q}(@ 40 \% \text { as seed }) \\
1296 \mathrm{ha}\end{array}$ \\
\hline & & & & Total & 5832 ha (67.81 times) \\
\hline \multirow[t]{3}{*}{ Paddy } & $2012-13$ & 6 q (30 ha) & $\begin{array}{l}1200 \mathrm{q} \\
\text { (@ } 40 \mathrm{q} / \mathrm{ha})\end{array}$ & $\begin{array}{l}480 \mathrm{q} \text { (@ } 90 \% \text { as seed }) \\
2400 \text { ha }\end{array}$ & $\begin{array}{l}96000 \mathrm{q}(@ 40 \mathrm{q} / \mathrm{ha}) \\
38400 \text { ha (@40\% as seed) }\end{array}$ \\
\hline & \multirow[t]{2}{*}{ 2013-14 } & \multirow[t]{2}{*}{$\begin{array}{l}28 \\
(140 \mathrm{ha})\end{array}$} & \multirow[t]{2}{*}{--} & $\begin{array}{l}5600 \mathrm{q} \\
(@ 40 \mathrm{q} / \mathrm{ha})\end{array}$ & $\begin{array}{l}\text { 2240q (@40\% as seed) } \\
11200 \text { ha }\end{array}$ \\
\hline & & & & Total & 49600 ha (291.76 times) \\
\hline
\end{tabular}

As shown in above graph, the $\mathrm{BC}$ ratio for wheat (2.20) and paddy (2.01) were worked out to be higher even when the seeds were disseminated from the far-off distance of ICAR-IARI, New Delhi by meeting the expenses of postal and other miscellaneous charges as compared the quality seed of wheat (B: $\mathrm{C}-1.86$ ) and paddy (B: C- 1.70) made available locally either from the market or the Government agencies. This analysis also reiterated for popularizing the more profitable crop varieties with higher yield potential even if it has to be brought from far distance and in this endeavour rural post-offices are proved to the effective instrument. The details are furnished as below:

\section{Diffusion effect of quality seeds of crops}

Horizontal diffusion of IARI wheat varieties (HD 2967, HD 2733 and HD 2985) was assessed to the extent of 43 times of the initial area started in 2009-10 and after the end of the project in 2014-15. Similarly, for IARI paddy varieties (P 2511, P 44, PB 1121, Jaldi dhan and others), the diffusion effect was still more encouraging as the area coverage after five years of project was 295 times of the area started initially.

As a specific case of paddy and wheat for the year 2012 to 2015, the extent of diffusion of the quality seed has been analyzed as below:

\section{Economic viability of model on cost} sharing approach

In order to sustain the model even after the termination of the experiment, provision of cost sharing was made as the inbuilt mechanism. Therefore, the feasibility of model on cost sharing basis was analyzed.

The experiment was executed on 50\% sharing of cost of seed and postal charges by the farmers and related data were captured. Based on the results, it was also extrapolated for $100 \%$ cost sharing basis. The experiences showed that on $50 \%$ cost sharing basis, the B: $C$ ratio for high volume crop - wheat (1.93) and low volume crop - mustard (4.11) were encouraging. However, on $100 \%$ cost sharing basis, these ratios were slightly reduced to 1.89 and 3.78 respectively. 


\section{Empirical and operational models} validated

Feedbacks from the farmers and post office personnel as well as the related issues as experienced by them were ascertained. Majority of the farmers and village post masters $(45.5 \%)$ perceived that IARI-Post office linked extension model was highly effective in increasing awareness about IARI varieties. More than half of the farmers (56\%) reported that introduction of new variety of major crops increased the seed replacement rate.

More than three-fourth of the farmers (84\%) felt that prestige and social recognition in the community increased significantly. This made them "Star Farmer" in the community. Similarly, post office staff expressed that the frequency of farmers visiting post office and village post master increased significantly and post masters were acting as opinion leader in the community, social network and communication pattern in the rural society changed, social recognition of the village post masters enhanced (doing meaningful community service), there was selfsatisfaction among them and they also got the additional income.

The empirical model emanated was published by Dubey et al., $(2012,2014)$ and the operational framework was reported by Burman et al., (2015).

\section{Related issues and future research avenues}

To sustain the success of this model on large scale, seeds of latest varieties need to be sent to the KVKs for further multiplication and dissemination. In case, when the ICAR-IARI crop varieties are not relevant according to the situation of the districts, technology suitable for the area may be disseminated using this mechanism. The technology performance at the village level must be shared with ICARATARIs during various meetings and ought to be reflected in KVKs' Progress Report. Partner KVKs and selected village post masters may identify the beneficiary farmers in each season and seeds can be sent directly to the farmers through village post masters. Seed delivery channel may be critically looked into to evaluate its efficiency and assess seed quality once the seed is delivered to the farmers (Fig. 1 and 2).

The future research areas in this direction may include assessing the impact of such model for large scale seed or technology dissemination, delineation and analysis of supporting and otherwise organizational factors in this process, how the farmers' institution as the seed grower could be developed and seed could be sold through post offices using retail post mechanism and lastly the scope for utilizing media post and other related services of post offices for the benefit of rural audience may also be assessed.

\section{References}

Bennet C (1992).A New Interdependence ModelImplication for Extension Education, INTERPAKS Digest, Vol. 1, Fall 1992.

Birner, R, and J Anderson (2007) How to make agricultural extension demand-driven? The case of India's agricultural extension policy. Discussion Paper 00729. Washington D.C.: International Food Policy Research Institute.

Birner, R, K Davis, J Pender, E Nkonya, P Anandajayasekeram, J Ekboir, J (2004) From Best Practice to Best Fit: A Framework for Designing and Analyzing Pluralistic Agricultural Advisory Services Worldwide. J. Agril. Ext. Edu, 15(4): 341355.

Chambers, Robert, Arnold Pacey; Lori Ann Thrupp (1989) Farmers first: Farmer Innovation and agriculture research, London: Intermediate Technology Publications, P:219. 
Chandragowda, MJ (2011) Extension planning and management in agriculture and allied sector. In Presentation to the Third meeting of the Sub-Group on Extension Planning and Management constituted by the Planning Commission, New Delhi.

Department of Post https://www.indiapost.gov.in/.

Dubey, SK, Burman, RR, Sharma, JP, Vijayaragavan, K, Sangeetha, V, Singh, Ishwari and Gupta, HS, (2014) Can post offices of rural India be the driver for agricultural technology dissemination? Experiences of action research. Current Science, 107 (2), 25 July 2014.

Dubey, SK, Burman, RR, Vijayaragavan, K, Sharma, JP, Singh, Ishwari, Sangeetha, V and Gupta, HS. (2012) Linking research institute with post offices for dissemination of agricultural technologies: an action research. Indian J. Agril. Sci, 82 (12): 105967.

Duraisumy DG, Market Led Extension: Emerging Perspectives (2007) (In Kaleel FMH, Krishnonkutty J and Babu SK (Eds). Market Led Extension - Dimensions and Tools. Agrotech Publishing Academy, Udaipur. pp. 42-51.

Feder, GR Birner, and J Anderson (2011) The Private Sector's Role in Agricultural Extension Systems: Potential and Limitations. J. of Agribusiness in Developing and Emerging Eco., 1(1): 31-54.

GFRAS (2012) Fact Sheet on Extension Services. Position Paper. Global Forum for Rural Advisory Services (GFRAS) June.

ITU (2010) ICTs: new services and transformation off post. International
Telecom Union, Geneva and Universal Postal Union, Bern, 2010. Pp. 133.

Lundvall BA. (ed) (1992) National Innovation System: Towards a theory of Innovation and Interactive Learnings. Pinter, London.

Moni M. (2004) Ushering market-led agriculture extension.

R Roy Burman, Sujit Sarkar, V Sangeetha, SK Dubey, JP Sharma, Ishwari Singh, K Vijayaragavan and HS Gupta. (2015) Critical Analysis of IARI-Post Office Linkage Extension Model: An Innovative Extension Approach to Reach the Unreached. Indian Res. J. Ext. Edu. 15 (1): 12-19.

Ragasa, C, Ulimwengu,. Randriamamonjy, J and Badibanga $T$ (2013) Assessment of the Capacity, Incentives, and Performance of Agricultural Extension Agents in Western Democratic Republic of Congo. IFPRI Discussion Paper 01283. IFPRI, Washington.

Rivera, WM, KM Qamar, and LV Crowder (2001) Agricultural and Rural Extension Worldwide: Options for Institutional Reform in Developing Countries. Rome: FAO.

Rogers EM (1962). Diffusion of Innovations. Glencoe: Free Press, Ch. 7.

Samanta RK (1991). Agricultural Extension in Changing World Perspective. Uppal Publishing House, New Delhi. Pp. 137-141.

Scoone Ian and John Thompson eds. (1994) Beyond farmer first: Rural people's knowledge, agricultural research and extension practice. London: Intermediate Technology Publications, Pp. 219.

\section{How to cite this article:}

Dubey, S.K., R.R. Burman, J.P. Sharma, K. Vijayaragavan, Sujit Sarkar and Gupta, H.S. 2018. Institutionalizing the Empirical Evidences on Successful Case of Institute-Post Office Linked Technology Dissemination Model in India. Int.J.Curr.Microbiol.App.Sci. 7(1): 3556-3564. doi: https://doi.org/10.20546/ijcmas.2018.701.417 